\title{
Analisis Jalur Respons Hasil Kedelai (Glycine max (L.) Merr.) Varietas Unggul Nasional Terhadap Dua Cara Pemberian Kombinasi Pupuk Npk
}

\author{
Path Analysis Response of Soybean Yield (Glycine Max (L.) Merr.) National Level \\ Variety Against Two Ways of Combining NPK Fertilizer
}

\section{Paul Benyamin Timotiwu*, Yayuk Nurmiaty, Eko Pramono, dan Yosep Riando Kusuma}

Fakultas Pertanian, University of Lampung, Lampung, Indonesia

E-mail: paul.timotiwu@fp.unila.ac.id

\begin{abstract}
Path analysis is one of the causal analysis and is an advanced analysis of correlation and regression studies. Path analysis is the development of correlation analysis that explains the closeness of the relationship between characters by way of outlining correlation coefficients into direct and indirect effects. This research was aimed to obtain information on the direct and indirect effects of agronomic characteristics on the production. This research uses Siti Maysaroh research data entitled "The Effect of NPK Fertilizer on the Growth and Production of Four Soybean Varieties (Glycine max (L.) Merr)". The data that have been obtained will then be analyzed using path analysis method. Data is analyzed using Microsoft excel program. The results of this study show the difference between the two models, namely: on the way of fertilizer feeding two variables that directly affect the yield of soybean production is the weight of 100 grains, whereas on the way of giving a one-time fertilizer variable that directly affects the yield of soybean production is the number of pod.
\end{abstract}

Keywords : path analysis, soybeans, derect effect and inderect effect

Disubmit : 18 April 2018 ; Diterima: 30 April 2018 ; Disetujui : 18 Mei 2018

\section{PENDAHULUAN}

Metode Analisis Jalur pertama kali dikembangkan oleh seorang ahli genetika bernama Sewall Wright pada tahun 1921 yang menjelaskan hubungan kausal dalam genetika populasi dengan demikian dapat diketahui karakter independen mana yang paling berpengaruh terhadap hasil. Analisis Jalur (Path Analysis) adalah salah satu analisis hubungan sebab-akibat dan merupakan analisis lanjutan dari studi korelasi dan regresi. Tujuan utama Analisis Jalur adalah untuk mengetahui pengaruh langsung dan tidak langsung dari satu variabel pada variabel lainnya. Dalam bidang pertanian, analisis ini sering digunakan pada bermacam-macam komoditas tanaman sebagai salah satu metoda seleksi karakter (Gaspersz, 1995). Analisis Jalur adalah pengembangan dari analisis korelasi yang menjelaskan keeratan hubungan antarkarakter dan cara menguraikan koefisien korelasi menjadi pengaruh langsung dan pengaruh tidak langsung. Nilai pengaruh langsung itu adalah nilai koefisien regresi yang telah dibakukan yang lebih dikenal dengan sebutan nilai koefisien beta (Wirnas, D., 2005).

Pengaruh langsung (direct effect) adalah pengaruh kausal hipotetis suatu variabel pada variabel kedua yang terjadi secara langsung tanpa melalui variabel ketiga. Pengaruh searah suatu variabel pada variabel 
lainnya dinyatakan dengan lambang anak panah (“ $\rightarrow$ ”). Misalnya, pengaruh langsung variabel $x$ pada variabel $y$ dinyatakan sebagai $x \rightarrow y$. Besaran pengaruh searah dinyatakan sebagai koefisien regresi (takterstandardisasi) atau koefisien jalur (terstandardisasi). Pengaruh tidak-langsung (indirect effect) adalah pengaruh kausal hipotetis suatu variabel pada variabel kedua yang terjadi melalui satu atau lebih variabel mediator (intervening variables). Misalnya, pengaruh tidak langsung variabel $x$ pada variabel $2 \mathrm{y}$ yang terjadi melalui variabel mediator $1 y$ dinyatakan sebagai $x \rightarrow y 1 \rightarrow y 2$ (Harlan, 2012).

Variabel- variabel yang sering diamati dalam Analisis Jalur misalnya tinggi tanaman, jumlah daun, bobot kering berangkasan, jumlah polong total/tanaman, jumlah polong isi/tanaman, bobot 100 butir kadar air $12 \%$, hasil kedelai (t/ha). Secara agronomi variabel-variabel tersebut berpengaruh langsung dan tidak langsung pada produksi kedelai. Produksi kedelai di Indonesia pada tahun 2012 sebesar 843,15 ribu ton biji kering (Badan Pusat Statistik, 2012); pada tahun 2013 sebesar 780,16 ribu ton biji kering (Badan Pusat Statistik, 2013). Produksi kedelai di Lampung pada tahun 2012 sebesar 8 ribu ton biji kering (Badan Pusat Statistik, 2012); pada tahun 2013 sebesar 6,16 ribu ton biji kering (Badan Pusat Statistik, 2013) dengan luas panen sebesar 254 hektar.

Variabel yang ada pada Analisis Jalur terdiri dari variabel endogen dan variabel eksogen. Variabel endogen adalah variabel yang dijelaskan atau dipengaruhi oleh variabel eksogen sehingga variabilitasnya ditentukan oleh model yang sifatnya bisa menjadi variabel respons dalam suatu persamaan dan bisa menjadi variabel respons dalam suatu persamaan lain sedangkan variabel eksogen adalah variabel penyebab atau berpengaruh pada variabel lain dan variabilitasnya ditentukan oleh penyebab di luar model (Pedhazur, 1982). Untuk mengetahui pengaruh langsung dan tidak langsung varabel - variabel yang berpengaruh pada hasil kedelai dianalisi menggunakan metode Analisis Jalur.

\section{METODE PENELITIAN}

Penelitian ini menggunakan data hasil penelitian Siti Maysaroh yang berjudul "Respons Pertumbuhan dan Hasil Empat Varietas Kedelai (Glycine Max (L.) Merrill) Terhadap Cara Pemberian kombinasi Pupuk NPK" (Maysaroh, 2018). Data yang diperoleh kemudian dianalisis menggunakan Metode Analisis Jalur (path analysis) dengan Program Microsoft Excel (Sarwono, 2011). Tujuan menggunakan Metode Analaisis Jalur yaitu untuk memperoleh informasi pengaruh langsung dan tidak langsung antarkarakter agronomi pada hasil kedelai.

\section{HASIL DAN PEMBAHASAN}

Pengaruh langsung dan tidak langsung pemupukan NPK tunggal dosis rekomendasi yang

diberikan dua kali. Pengaruh langsung (direct effect) adalah pengaruh kausal hipotetis suatu variabel pada variabel kedua (mediator) yang terjadi secara langsung tanpa melalui variabel ketiga sedangkan pengaruh tidak-langsung (indirect effect) adalah pengaruh kausal hipotetis suatu variabel pada variabel kedua yang terjadi melalui satu atau lebih variabel mediator (Harlan, 2012). Pemupukan NPK tunggal dosis rekomendasi yang diberikan dua kali (dua tahap). Tahap pertama diberikan saat awal penanaman dan tahap kedua diberikann pada saat awal berpolong. Data variabel pengaruh langsung dan tidak langsung pemupukan NPK tunggal dosis rekomendasi yang diberikan dua kali ditampilkan pada Tabel 1.

Data Tabel 1 kemudian dilanjutkan ke tahap operasi corelation (korelasi). Operasi corelation dari data Tabel 1 menghasilkan matriks korelasi rxx. Matriks korelasi ditampilkan pada Tabel 2 yang menjelaskan hubungan korelasi antarvariabel pada hasil kedelai. Korelasi yang terlihat sangat dominan ditunjukan oleh variabel jumlah polong total, jumlah polong isi, dan bobot 100 butir dalam memmengaruhi hasil kedelai. Nilai korelasi yang cukup besar terdapat pada jumlah polong total $\left(\mathrm{x}_{4}\right)$ melalui jumlah polong isi $\left(\mathrm{x}_{5}\right)$ yaitu 0,95 dan bobot 100 butir $\left(\mathrm{x}_{6}\right)$ melalui jumlah daun $\left(\mathrm{x}_{2}\right)$ yaitu $-0,63$. 
Timotiwu dkk: Analisis Jalur Respons Hasil Kedelai (Glycine max (L.) Merr.) Varietas Unggul Nasional...

Tabel 1. Data variabel pengaruh langsung dan tidak langsung pemupukan NPK tunggal dosis rekomendasi yang diberikan dua kali.

\begin{tabular}{lccccccc}
\hline & $\mathrm{TT}(\mathrm{cm})$ & $\mathrm{JD}($ Helai) & $\mathrm{BKB}(\mathrm{g})$ & JPT(Polong) & JPI(Polong isi) & B.100(g) & $\mathrm{Y}(\mathrm{t} / \mathrm{ha})$ \\
\hline $\mathrm{P}_{1} \mathrm{~V}_{1}$ & 31,63 & 33,5 & 7,15 & 95 & 99 & 22,13 & 2,45 \\
$\mathrm{P}_{1} \mathrm{~V}_{2}$ & 27,25 & 22 & 2,62 & 84,5 & 75,5 & 23,34 & 1,72 \\
$\mathrm{P}_{1} \mathrm{~V}_{3}$ & 24,38 & 33,25 & 8,54 & 79 & 74 & 17,78 & 1,55 \\
$\mathrm{P}_{1} \mathrm{~V}_{4}$ & 32,68 & 29 & 4,7 & 70 & 66 & 18,03 & 1,05 \\
$\mathrm{P}_{1} \mathrm{~V}_{1}$ & 38 & 28,25 & 12,36 & 88 & 88 & 31,33 & 2,31 \\
$\mathrm{P}_{1} \mathrm{~V}_{2}$ & 38 & 42 & 5,46 & 82 & 76 & 17,23 & 1,87 \\
$\mathrm{P}_{1} \mathrm{~V}_{3}$ & 38,38 & 43,25 & 10,04 & 79,5 & 74 & 19,05 & 1,49 \\
$\mathrm{P}_{1} \mathrm{~V}_{4}$ & 40,75 & 35,5 & 7,06 & 69 & 68,5 & 18,23 & 1,11 \\
$\mathrm{P}_{1} \mathrm{~V}_{1}$ & 41,38 & 24 & 6,88 & 84,5 & 80 & 28,12 & 2,22 \\
$\mathrm{P}_{1} \mathrm{~V}_{2}$ & 35,13 & 43 & 5,35 & 74 & 70,5 & 19 & 1,60 \\
$\mathrm{P}_{1} \mathrm{~V}_{3}$ & 30,5 & 29 & 3,17 & 66,5 & 62 & 21,95 & 1,60 \\
$\mathrm{P}_{1} \mathrm{~V}_{4}$ & 31,88 & 38,5 & 5,17 & 67 & 62 & 18,08 & 1,18 \\
\hline
\end{tabular}

\begin{tabular}{|c|c|c|c|}
\hline Keterangan $: \mathrm{x}_{1}$ & $=$ Tinggi tanaman & P1 & $=$ Perlakuan ke-1 \\
\hline $\mathrm{x}_{2}$ & $=$ Jumlah daun & V1 & $=$ Varietas Anjasmoro \\
\hline $\mathrm{x}_{3}$ & $=$ Bobot brangkasan & V2 & $=$ Varietas Grobokan \\
\hline $\mathrm{X}_{4}$ & $=$ Jumlah polong total & V3 & = Varieatas Dena-1 \\
\hline $\mathrm{X}_{5}$ & $=$ Jumlah polong isi & V4 & $=$ Varietas agromulyo \\
\hline $\mathrm{X}_{6}$ & $=$ Bobot 100 butir & TT & $=$ Tinggi tanaman \\
\hline Y & $=$ hasil kedelai & JD & $=$ Jumlah daun \\
\hline BKB & $=$ Bobot Kering Berangkasan & JPI & $=$ Jumlah polong isi \\
\hline JPT & $=$ Jumlah Polong Total & B. 1 & $=$ Bobot seratus butir \\
\hline
\end{tabular}

Pengerjaan operasi regresi dan deskripsi data Tabel 1 untuk model 1 (pemupukan dua kali) memberikan hasil nilai regresi dan deskripsi yaitu nilai regresi $b_{1}=-0,007, b_{2=} 0,026, b_{3}=-0,051, b_{4}=0,016, b_{5}=0,018, b_{6=}$ 0,075 sedangkan nilai deskripsi memberikan nilai yaitu $\mathrm{Sx} 1=5,35, \mathrm{Sx} 2=7,24$, $\mathrm{Sx} 3=2,79, \mathrm{Sx} 4=9,08, \mathrm{Sx} 5=$ 10,68, Sx6 $=4,50$, dan $\mathrm{Sy}=0,46$.

Tabel 2. Matriks korelasi rxx pengaruh langsung dan tidak langsung dosis rekomendasi yang diberikan dua kali.

\begin{tabular}{lrrrrrrr}
\hline & \multicolumn{1}{l}{ TT } & \multicolumn{1}{c}{ JD } & \multicolumn{1}{l}{ BKB } & \multicolumn{1}{l}{ JPT } & \multicolumn{1}{c}{ JPI } & \multicolumn{1}{l}{ B.100 } & \multicolumn{1}{c}{ Y } \\
\hline TT & 1 & 0,23 & 0,38 & 0,04 & 0,11 & 0,26 & 0,14 \\
JD & 0,24 & 1 & 0,19 & $-0,22$ & $-0,17$ & $-0,63$ & $-0,28$ \\
BKB & 0,38 & 0,19 & 1 & 0,41 & 0,50 & 0,38 & 0,35 \\
JPT & 0,04 & $-0,22$ & 0,42 & 1 & 0,95 & 0,53 & 0,87 \\
JPI & 0,11 & $-0,17$ & 0,50 & 0,95 & 1 & 0,53 & 0,87 \\
B.100 & 0,25 & $-0,63$ & 0,37 & 0,53 & 0,53 & 1 & 0,71 \\
Y & 0,14 & $-0,28$ & 0,35 & 0,87 & 0,87 & 0,71 & 1 \\
\hline
\end{tabular}

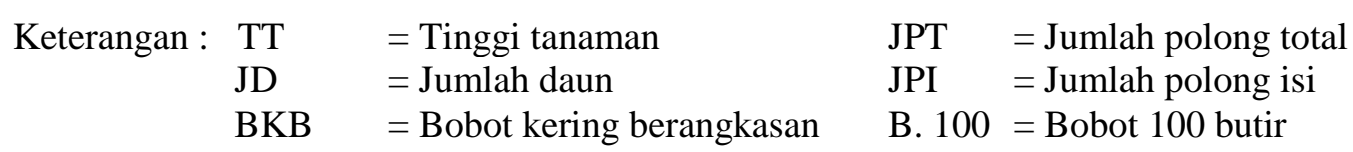


Berdasarkan rumus $\mathbf{C i}=$ bi ( Sxi/Sxy) (Susilo \& Timotiwu, 2017) diperoleh nilai-nilai koefesien lintasan pengaruh langsung variabel-variabel yang diamati pada hasil benih yaitu: $\mathrm{C} 1=-0,091, \mathrm{C} 2=0,410, \mathrm{C} 3=$ $-0,311, \mathrm{C} 4=0,309, \mathrm{C} 5=0,419, \mathrm{C} 6=0,734$. Koefesien lintasan pengaruh langsung $(=\mathrm{Ci})$ yang telah diperoleh itu dinyatakan dalam matriks Ci yang ditampilkan pada Gambar 1.

$$
\mathrm{Ci}=\left[\begin{array}{c}
-0,09 \\
0,41 \\
-0,31 \\
0,30 \\
0,42 \\
0,73
\end{array}\right]
$$

Gambar 1. Matriks Ci pengaruh langsung pemupukan NPK tunggal dosis rekomendasi yang diberikan dua kali.

Perkalian antara matriks $\mathbf{r}_{\mathbf{x x}}$ dan matriks $\mathbf{C i}$ menghasilkan matriks $\mathbf{r}_{\mathbf{x y}}$. Menurut Susilo \& Timotiwu, (2017) matriks $\mathbf{r}_{\mathbf{x y}}$ merupakan matriks korelasi antara $\mathrm{x}$ dan $\mathrm{y}$ sehingga unsur-unsur koefesien korelasi adalah $\mathrm{x}$ dan y. Namun demikian, karena matriks $\mathbf{r}_{\mathbf{x y}}$ ini juga merupakan hasil kali $\mathbf{r}_{\mathbf{x x}} \mathbf{C}$ sehingga unsur-unsurnya juga merupakan gabungan antara koefesien lintasan pengaruh langsung dan koefesien pengaruh tidak langsung $\mathrm{x}$ pada $\mathrm{y}$. Koefesien lintasan pengaruh variabel x pada y ditampilkan pada Tabel 3 .

Tabel 3. Koefesien lintasan pengaruh langsung dan tidak langsung $\mathrm{x}$ pada y dosis rekomendasi yang diberikan dua kali.

\begin{tabular}{|c|c|c|c|c|c|c|c|}
\hline Langsung & & $\begin{array}{c}\text { TT } \\
-0,091585226 \\
\end{array}$ & $\begin{array}{c}\text { JD } \\
0,410842658 \\
\end{array}$ & $\begin{array}{c}\text { BKB } \\
-0,311683391\end{array}$ & $\begin{array}{c}\text { JPT } \\
0,309056375 \\
\end{array}$ & $\begin{array}{c}\text { JPI } \\
0,419296523 \\
\end{array}$ & $\begin{array}{c}\text { B.100 } \\
0,734110525 \\
\end{array}$ \\
\hline & TT & & $-0,021731568$ & $-0,034568626$ & $-0,004311029$ & $-0,010885574$ & $-0,02364336$ \\
\hline & JD & 0,09748576 & & 0,077833619 & $-0,092987852$ & $-0,069824864$ & $-0,262756614$ \\
\hline Tidak & BKB & $-0,117644154$ & $-0,059048002$ & & $-0,130877644$ & $-0,155853808$ & $-0,117812067$ \\
\hline \multirow{3}{*}{ Langsung } & JPT & 0,014547663 & $-0,069950108$ & 0,129774545 & & 0,295058678 & 0,16541833 \\
\hline & JPI & 0,04983646 & $-0,071261643$ & 0,209664556 & 0,400305858 & & 0,222401177 \\
\hline & B.100 & 0,189515717 & $-0,469504303$ & 0,277483756 & 0,392922933 & 0,389383225 & \\
\hline Total & & 0,142156219 & $-0,280652986$ & 0,348504458 & 0,874108642 & 0,867174208 & 0,717717991 \\
\hline Keterangan & $\begin{array}{l}\text { TT } \\
\text { JD } \\
\text { BKB } \\
\text { JPT }\end{array}$ & $\begin{array}{l}=\text { Tinggi } \mathrm{t} \\
=\text { Jumlah } \\
=\text { Bobot } \mathrm{k} \\
=\text { Jumlah }\end{array}$ & $\begin{array}{l}\text { naman } \\
\text { aun } \\
\text { ring berangka } \\
\text { olong total }\end{array}$ & $\begin{array}{l}\text { JPI } \\
\text { B. } 100\end{array}$ & $\begin{array}{l}\text { Jumlah polo } \\
\text { Bobot } 100 \mathrm{~b}\end{array}$ & & \\
\hline
\end{tabular}

Total pengaruh $\mathrm{x}_{1}$ sampai dengan $\mathrm{x}_{6}$ berturut-turut yaitu $0,14,-0,28,0,35,0,88,0,87,0,71$. Dari nilai total pengaruh langsung dan tidak langsung, total pengaruh yang memiliki nilai terbesar yaitu terdapat pada variabel $\mathrm{x}_{6}$ (bobot 100 butir). Pengaruh langsung dari variabel $\mathrm{x}_{6}$ yaitu 0,73 . Pengaruh tidak langsung dari variabel $\mathrm{x}_{6}$ melalui $\mathrm{x}_{1}$ sampai dengan $\mathrm{x}_{6}$ berturut -turut yaitu $-0,02,-0,26,-0,11,0,16,0,22$. Hubungan antarvariabel Analisis Jalur diilustrasikan dalam sebuah diagaram lintasan atau diagram jalur yang ditampilkan pada Gambar 2.

Variabel - variabel dalam Model 1 (pemupukan dua kali) yang menyumbang atau berkontribusi terhadap hasil kedelai diuji dengan Uji t-Student. Hasil uji t-hitung terhadap variabel-variabel tersebut ditampilkan pada Tabel 4. Penentuan variabel nyata atau tidak nyata dalam memengaruhi hasil kedelai ditunjukkan oleh nilai p-value. Menurut (Kurniawan, 2008), definisi p-value (probability value) adalah tingkat keberartian terkecil sehingga nilai suatu uji statistik yang sedang diamati masih berarti atau besarnya peluang melakukan kesalahan. Nilai p-value lebih dari $0,05(\mathrm{P}>0,05)$ disimpulkan bahwa variabel tidak nyata sedangkan p-value kurang dari 0,05 ( $<<0,05)$ disimpulkan bahwa variabel nyata memengaruhi hasil kedelai. Kemudian dari hasil uji hitung diperoleh persamaan linier $\hat{y}=-2,778+0,037 x_{6}$. 


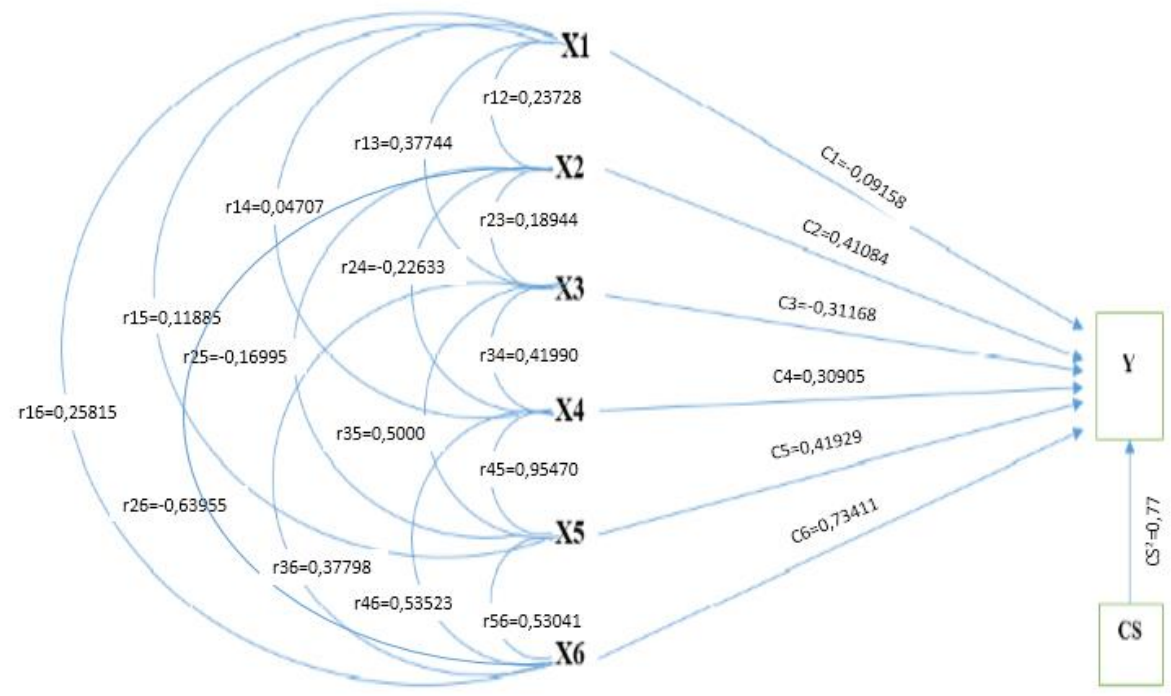

Gambar 2. Diagram lintasan pengaruh variabel eksogen $\mathrm{x}_{1}, \mathrm{x}_{2}, \mathrm{x}_{3}, \mathrm{x}_{4}, \mathrm{x}_{5}, \mathrm{x}_{6}$ pada variabel endogen $\mathrm{y}$.

Pengaruh langsung dan tidak langsung pemupukan NPK tunggal dosis rekomendasi yang diberikan satu kali. Pemupukan NPK tunggal sesuai rekomendasi yang diberikan satu kali, pupuk diberikan dalam satu tahap. Pupuk NPK hanya diberikan saat awal penanaman. Data variabel pengaruh langsung dan tidak langsung pemupukan NPK tunggal dosis rekomendasi yang diberiakan satu kali ditampilkan pada Tabel 5 .

Tabel 4. Hasil Uji hitung variabel-variabel yang berkontribusi pada hasil kedelai Model 1.

\begin{tabular}{ccccccc}
\hline & Coefficients & $\begin{array}{c}\text { Standard } \\
\text { Error }\end{array}$ & t Stat & P-value & $\begin{array}{c}\text { Lower } \\
95 \%\end{array}$ & $\begin{array}{c}\text { Upper } \\
95 \%\end{array}$ \\
\hline Intercept & $-2,78$ & 0,90 & $-3,09$ & 0,03 & $-5,09$ & $-0,47$ \\
TT & $-0,01$ & 0,01 & $-0,58$ & $0,59 \mathrm{tn}$ & $-0,04$ & 0,03 \\
JD & 0,03 & 0,01 & 1,78 & $0,13 \mathrm{tn}$ & $-0,01$ & 0,06 \\
BKB & $-0,05$ & 0,03 & $-1,75$ & $0,14 \mathrm{tn}$ & $-0,13$ & 0,02 \\
JPT & 0,02 & 0,02 & 0,70 & $0,51 \mathrm{tn}$ & $-0,04$ & 0,07 \\
JPI & 0,02 & 0,02 & 0,93 & $0,39 \mathrm{tn}$ & $-0,03$ & 0,07 \\
B.100 & 0,08 & 0,03 & 2,82 & $0,04 *$ & 0,01 & 0,14 \\
\hline
\end{tabular}

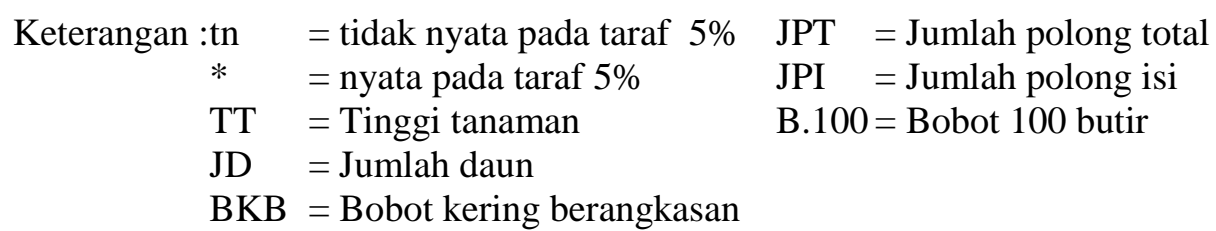

Data pada Tabel 5 kemudian dilanjutkan ke tahap operasi corelation (korelasi). Matriks korelasi ditampilkan pada Tabel 6, tabel ini menjelaskan hubungan korelasi antarvariabel pada hasil kedelai. Korelasi yang sangat dominan ditunjukan pada variabel jumlah polong total, jumlah polong isi, dan bobot 100 butir dalam mempengaruhi hasil kedelai. Namun, jika dilihat dari nilai besarnya korelasi, sumbangan $\mathrm{x}_{5}$ (jumlah polong isi) melalui $\mathrm{x}_{4}$ (variabel jumlah polong total) sangat tinggi yaitu 0,90 pada hasil kedelai. Hal ini berarti, 
tingkat pengisian fotosintat (kebernasan) pada polong kedelai sangat baik, sehingga menyebabkan jumlah polong isi tinggi.

Tabel 5. Data variabel pengaruh langsung dan tidak langsung pemupukan NPK tunggal dosis rekomendasi yang diberikan satu kali.

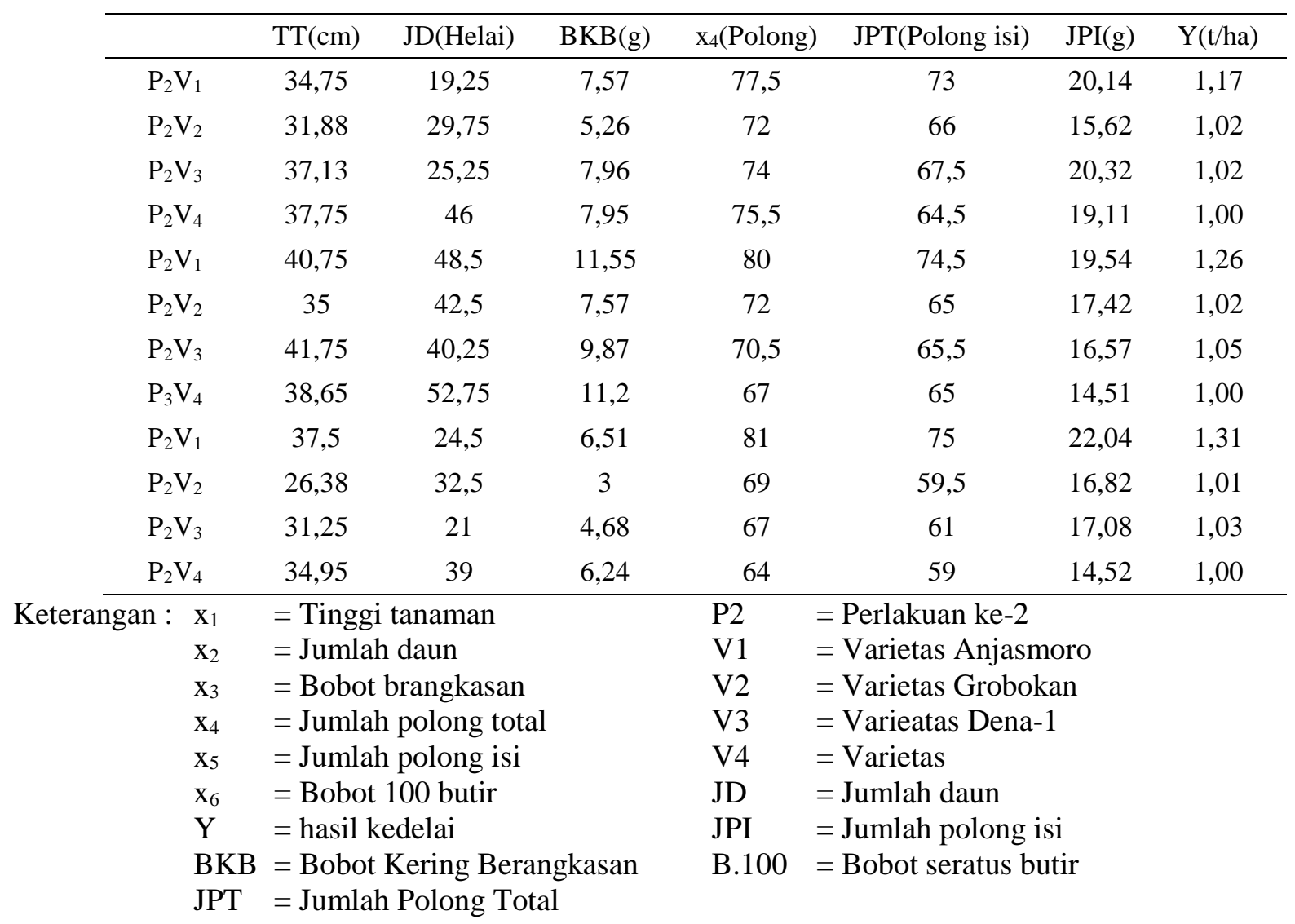

Pengerjaan operasi regresi dan deskripsi data Tabel 5 untuk Model 1( pemupukan satu kali) memberikan hasil nilai regresi dan deskripsi. Nilai regresi yaitu $b_{1}=0,006, b_{2}=0,007, b_{3}=-0,050, b_{4}=-0,029, b_{5}=0,044, b_{6}=$ 0,030 sedangkan nilai deskripsi yaitu $\mathrm{Sx}_{1}=4,30, \mathrm{Sx}_{2}=11,28, \mathrm{Sx}_{3}=2,55, \mathrm{Sx}_{4}=5,34, \mathrm{Sx}_{5}=5,42, \mathrm{Sx}_{6}=2,41$, dan $\mathrm{Sy}=0,10$. Berdasarkan rumus $\mathrm{Ci}=$ bi ( Sxi/Sxy) (Susilo \& Timotiwu, 2017) diperoleh nilai-nilai koefesien lintasan pengaruh langsung variabel-variabel yang diamati pada hasil benih kedelai yaitu $\mathrm{C} 1=0,27, \mathrm{C} 2=0,74$ $, \mathrm{C} 3=-1,16, \mathrm{C} 4=-1,40, \mathrm{C} 5=2,17, \mathrm{C} 6=0,64$. Koefesien lintasan pengaruh langsung $(=\mathrm{Ci})$ yang telah diperoleh itu dapat dinyatakan dalam matriks, yaitu matriks $\mathbf{C i}$ yang ditampilkan pada Gambar 3.

$$
\mathrm{Ci}=\left[\begin{array}{c}
0,27 \\
0,74 \\
-1,16 \\
-1,40 \\
2,17 \\
0,64
\end{array}\right]
$$

Gambar 3. Matriks Ci (Pengaruh langsung) pemupukan NPK tunggal dosis sesuai rekomendasi yang diberikan satu kali.

Perkalian antara matriks $r_{x x}$ dan matriks Ci menghasilkan menghasilkan matriks $r_{x y}$. Menurut Susilo \& Timotiwu, (2017), matriks $\mathrm{r}_{\mathrm{xy}}$ merupakan matriks korelasi antara $\mathrm{x}$ dan y sehinggs unsur-unsurnya ialah 
Timotiwu dkk : Analisis Jalur Respons Hasil Kedelai (Glycine max (L.) Merr.) Varietas Unggul Nasional...

koefesien korelasi antara $\mathrm{x}$ dan y. Namun demikian, karena matriks $\mathbf{r}_{\mathbf{x y}}$ ini juga merupakann hasil kali $\mathbf{r}_{\mathbf{x x}} \mathbf{C}$, maka unsur-unsurnya juga merupakan gabungan antara koefesien lintasan pengaruh langsung dan koefesien pengaruh tidak langsung $\mathrm{x}$ pada $\mathrm{y}$. Koefesien lintasan pengaruh variabel $\mathrm{x}$ pada $\mathrm{y}$ dapat ditampilkan pada Tabel 7.

Tabel 6. Matriks korelasi rxx pengaruh langsung dan tidak langsung dosis rekomendasi yang diberikan satu kali.

\begin{tabular}{cccccccc}
\hline & TT & JD & BKB & JPT & JPI & B.100 & Y \\
\hline TT & 1 & 0,47 & 0,90 & 0,37 & 0,52 & 0,23 & 0,34 \\
JD & 0,47 & 1 & 0,63 & $-0,16$ & $-0,13$ & $-0,41$ & $-0,20$ \\
BKB & 0,90 & 0,63 & 1 & 0,28 & 0,48 & 0,07 & 0,25 \\
JPT & 0,37 & $-0,16$ & 0,28 & 1 & 0,90 & 0,88 & 0,80 \\
JPI & 0,52 & $-0,13$ & 0,48 & 0,90 & 1 & 0,75 & 0,88 \\
B.100 & 0,23 & $-0,41$ & 0,07 & 0,88 & 0,75 & 1 & 0,71 \\
Y & 0,34 & $-0,20$ & 0,25 & 0,80 & 0,87 & 0,71 & 1 \\
\hline
\end{tabular}

$\begin{array}{llll}\text { Keterangan : } & \text { TT = Tinggi tanaman } & \text { JPT } & \text { Jumlah polong total } \\ \text { JD } & \text { Jumlah daun } & \text { JPI } & =\text { Jumlah polong isi } \\ \text { BKB } & =\text { Bobot kering berangkasan } & \text { B. } 100=\text { Bobot } 100 \text { butir }\end{array}$

Total pengaruh $\mathrm{x}_{1}$ sampai dengan $\mathrm{x}_{6}$ berturut-turut yaitu $0,34,-0,20,0,25,0,80,0,87,0,71$ pada hasil kedelai. Dari nilai total pengaruh langsung dan tidak langsung, total pengaruh yang memiliki nilai terbesar yaitu terdapat pada variabel $\mathrm{x}_{5}$ (jumlah polong isi). Pengaruh langsung dari variabel $\mathrm{x}_{5}$ yaitu 2,17. Pengaruh tidak langsung dari variabel $\mathrm{x}_{5}$ melalui $\mathrm{x}_{1}$ sampai dengan $\mathrm{x}_{6}$ berturut -turut yaitu $0,14,-0,10,-0,55,-1,26,0,48$. Hubungan antar variabel pada analisis jalur diilustrasikan dalam sebuah diagaram lintasan atau diagram jalur yang ditampilkan pada Gambar 4.

Tabel 7. Koefesien lintasan pengaruh langsung dan tidak langsung x pada y dosis rekomendasi satu kali.

\begin{tabular}{c|c|rrrrrr}
\hline \multirow{2}{*}{ Langsung } & & \multicolumn{1}{|c}{ TT } & JD & BKB & JPT & JPI & B.100 \\
& & 0,269347982 & 0,740437497 & $-1,159745056$ & $-1,391149991$ & 2,169153434 & 0,64748784 \\
\hline & TT & & 0,1283533 & 0,243519835 & 0,100234542 & 0,141089933 & 0,063092945 \\
& JD & 0,352843173 & & 0,467982048 & $-0,11808577$ & $-0,100092823$ & $-0,308794073$ \\
Tidak & BKB & $-1,048535516$ & $-0,732998894$ & & $-0,326313525$ & $-0,557745341$ & $-0,087331892$ \\
Langsung & JPT & $-0,517699377$ & 0,221862099 & $-0,391423145$ & & $-1,263474973$ & $-1,232028701$ \\
& JPI & 1,136246538 & $-0,293227573$ & 1,04319067 & 1,970075904 & & 1,631091146 \\
& B.100 & 0,151669652 & $-0,270030094$ & 0,048757559 & 0,573427457 & 0,486877353 & \\
\hline Total & & 0,343872451 & $-0,205603665$ & 0,252281911 & 0,808188617 & 0,875807583 & 0,713517264 \\
\hline
\end{tabular}

$\begin{array}{llll}\text { Keterangan : } & \text { TT = Tinggi tanaman } & \text { JPT } & \text { Jumlah polong total } \\ \text { JD } & \text { Jumlah daun } & \text { JPI } & =\text { Jumlah polong isi } \\ \text { BKB } & =\text { Bobot kering berangkasan } & \text { B. } 100=\text { Bobot } 100 \text { butir }\end{array}$

Variabel - variabel dalam Model 2 (pemupukan satu kali) yang menyumbang atau berkontribusi terhadap hasil kedelai diuji dengan Uji t-Student. Hasil uji t-hitung terhadap variabel-variabel tersebut ditampilkan pada Tabel 8. Penentuan variabel nyata atau tidak nyata dalam memengaruhi hasil kedelai ditunjukan oleh nilai p-value. Menurut (Kurniawan, 2008), definisi p-value (probability value) adalah tingkat keberartian terkecil sehingga nilai suatu uji statistik yang sedang diamati masih berarti atau besarnya peluang melakukan kesalahan. Nilai p-value lebih dari 0,05 $(\mathrm{P}>0,05)$ disimpulkan bahwa variabel tidak nyata 
sedangkan nilai p-value kurang dari $0,05(\mathrm{P}<0,05)$ disimpulkan bahwa variabel nyata. Kemudian dari hasil $\mathrm{t}$-student diperoleh persamaan linier $\hat{\mathrm{y}}=-0,42+0,03 \mathrm{x}_{5}$.

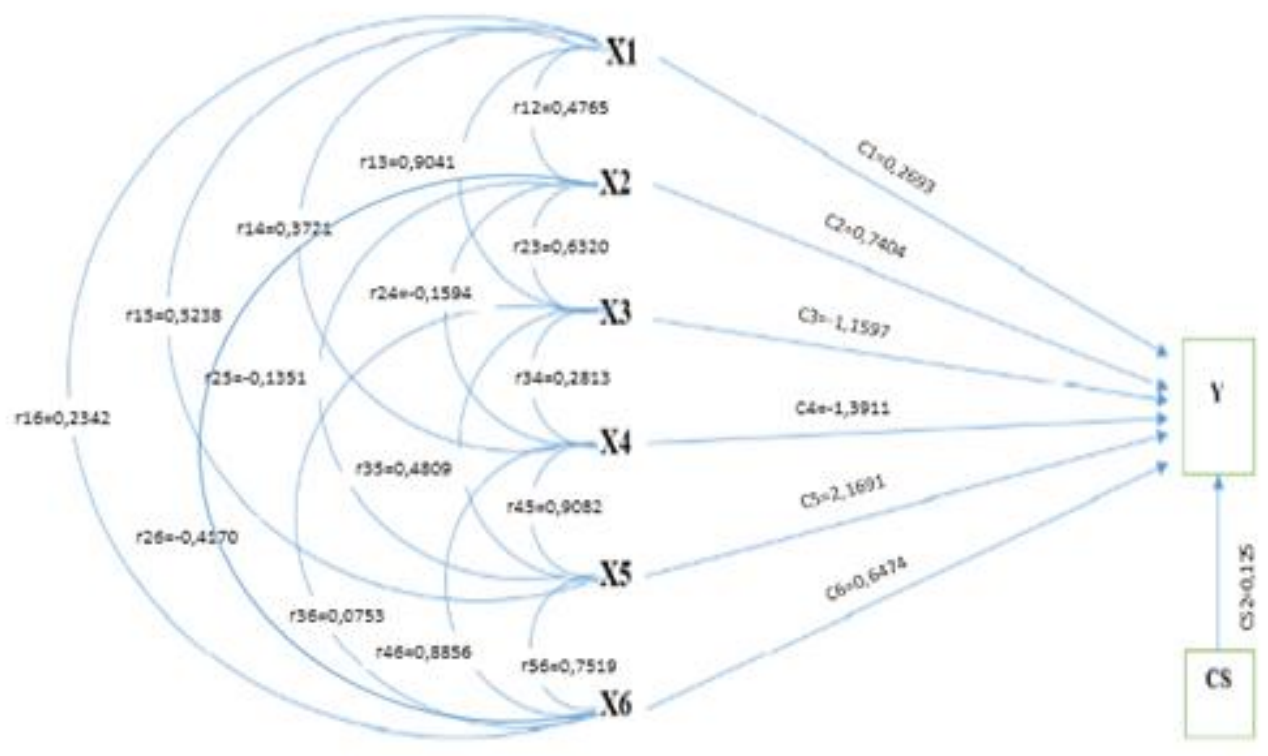

Gambar 4. Diagram lintasan pengaruh variabel eksogen $\mathrm{x} 1, \mathrm{x} 2, \mathrm{x} 3, \mathrm{x} 4, \mathrm{x} 5, \mathrm{x} 6$ pada variabel endogen $\mathrm{y}$.

Pengaruh langsung Model 1 yaitu cara pemupukan dua kali ditampilkan pada diagram jalur (Gambar 2) yang menunjukkan bahwa variabel $\mathrm{x}_{6}$ (bobot 100 butir) memberikan kontribusi pengaruh langsung yang cukup besar pada hasil kedelai. Variabel $\mathrm{x}_{1}$ dan $\mathrm{x}_{3}$ memberikan pengaruh negatif sedangkan $\mathrm{x}_{2}, \mathrm{x}_{4}, \mathrm{x}_{5}$, dan $\mathrm{x}_{6}$ memberikan pengaruh positif pada hasil kedelai. Selain Gambar 2, diagram jalur Model 1 ditampilkan juga pada Gambar 5 yang lebih rinci. Garis hijau pada diagram jalur menunjukkan besaran pengaruh langsung suatu variabel pada hasil kedelai.

Tabel 8. Hasil Uji hitung variabel-variabel yang berkontribusi pada hasil kedelai Model 2.

\begin{tabular}{ccccccc}
\hline & Coefficients & Standard Error & t Stat & P-value & Lower 95\% & Upper 95\% \\
\hline Intercept & $-0,42$ & 0,39 & $-1,06$ & 0,34 & $-1,43$ & 0,59 \\
TT & 0,01 & 0,01 & 0,68 & $0,52 \mathrm{tn}$ & $-0,02$ & 0,03 \\
JD & 0,01 & 0,00 & 1,76 & $0,14 \mathrm{tn}$ & 0,00 & 0,02 \\
BKB & $-0,05$ & 0,03 & $-1,95$ & $0,11 \mathrm{tn}$ & $-0,12$ & 0,02 \\
JPT & $-0,03$ & 0,02 & $-1,61$ & $0,17 \mathrm{tn}$ & $-0,07$ & 0,02 \\
JPI & 0,04 & 0,01 & 2,99 & $0,03 *$ & 0,01 & 0,08 \\
B.100 & 0,03 & 0,02 & 1,25 & $0,27 \mathrm{tn}$ & $-0,03$ & 0,09 \\
\hline
\end{tabular}

$$
\begin{array}{rlll}
\text { Keterangan : tn } & =\text { tidak nyata pada taraf } & \text { JPT } & \text { = Jumlah polong total } \\
* & =\text { nyata pada taraf 5\% } & \text { JPI }=\text { Jumlah polong isi } \\
\text { TT } & =\text { Tinggi tanaman } & \text { B.100 } & =\text { Bobot } 100 \text { butir } \\
\text { JD } & =\text { Jumlah daun } & & \\
\text { BKB } & =\text { Bobot kering berangkasan } & &
\end{array}
$$

Variabel yang berpengaruh langsung paling tinggi pada hasil kedelai yaitu variabel $\mathrm{x}_{6}$ yang memiliki nilai 0,73 kemudian diikuti variabel $\mathrm{x}_{5}, \mathrm{x}_{2}, \mathrm{x}_{4}, \mathrm{x}_{3}$, dan $\mathrm{x}_{1}$ berturut turut yaitu $0,42,0,41,0,30,-0,31,-0,09$. 
Timotiwu dkk : Analisis Jalur Respons Hasil Kedelai (Glycine max (L.) Merr.) Varietas Unggul Nasional...

Korelasi sangat dominan ditunjukkan oleh variabel jumlah polong total, jumlah polong isi, dan bobot 100 butir dalam memengaruhi hasil kedelai. Nilai korelasi yang cukup besar diperoleh dari jumlah polong total $\left(\mathrm{x}_{4}\right)$ melalui jumlah polong isi $\left(\mathrm{x}_{5}\right)$ yaitu 0,95 dan bobot 100 butir $\left(\mathrm{x}_{6}\right)$ melalui jumlah daun $\left(\mathrm{x}_{2}\right)$ yaitu $-0,63$. Berdasarkan Gambar 5 disimpulkan bahwa fotosintat yang terbentuk dari proses fotosintesis akan lebih fokus untuk pengisian biji sehingga bobot 100 butir akan meningkat. Menurut Nugraha (2014) menyatakan bahwa jika ketersediaan hara yang cukup maka fotosintesis berlangsung dengan baik dan fotosintat yang dihasilkan juga banyak serta fotosintat tersebut selanjutnya digunakan untuk pembentukan biji.

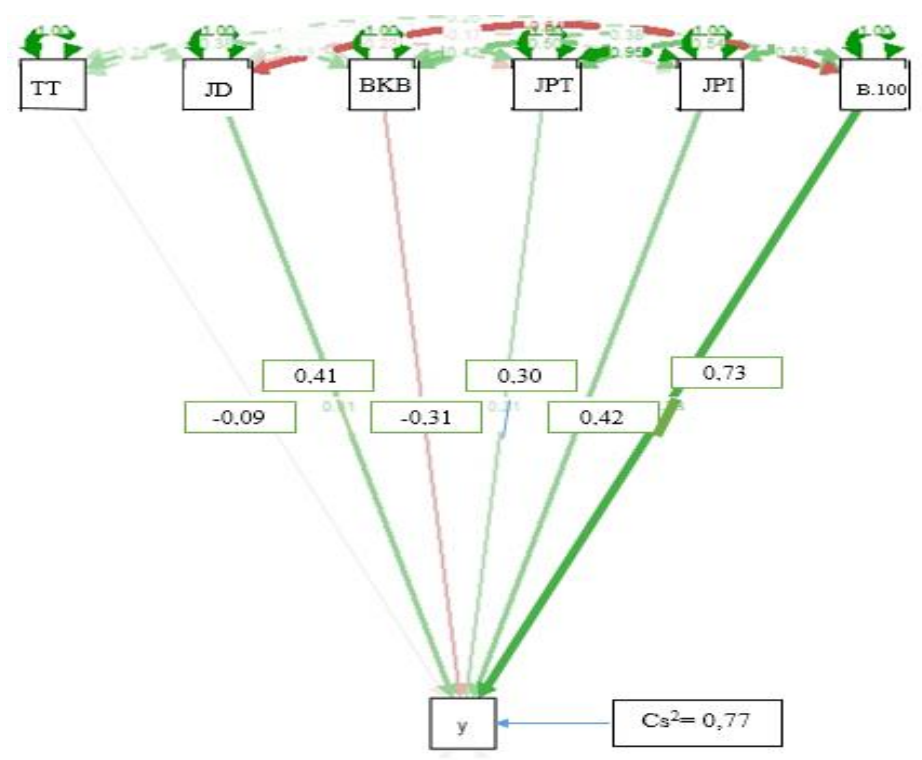

Gambar 5. Diagram lintasan pengaruh variabel eksogen $\mathrm{x}_{1}, \mathrm{x}_{2}, \mathrm{x}_{3}, \mathrm{x}_{4}, \mathrm{x}_{5}, \mathrm{x}_{6}$ pada variabel endogen $\mathrm{y}$.

Gambar 5 juga memberikan informasi tentang persentase keragaman variabel endogen yang disumbangkan oleh faktor lain di luar Model $1\left(\mathrm{Cs}^{2}=1-\mathrm{R}^{2}\right)$, dengan demikian nilai koefesien determinasi tersirat pada $\mathrm{Cs}^{2}$ sehingga $\mathrm{R}^{2}=1-\mathrm{Cs}^{2}$. Menurut Ghozali, (2011), koefisien determinasi $\left(\mathrm{R}^{2}\right)$ digunakan untuk mengukur seberapa jauh kemampuan model dalam menerangkan variasi variabel di luar model. Nilai Adjusted $R$ Squared $\left(\mathrm{R}^{2}\right)$ adalah koefisien determinasi yaitu koefisien yang menjelaskan seberapa besar proporsi variasi di luar model yang dapat dijelaskan oleh variabel - variabel dalam model secara bersama-sama. Nilai $\mathrm{R}^{2}$ Model 1 ditampilkan pada Tabel 9.

Tabel 9. Operasi regresion statistics Model 1

\begin{tabular}{ll}
\hline & Regression Statistics \\
\hline Multiple R & 0,96 \\
R Square & 0,923 \\
Adjusted R Square & 0,83 \\
Standard Error & 0,189 \\
Observations & 12,0 \\
\hline
\end{tabular}

Nilai $\mathrm{R}^{2}$ yang diperoleh dari operasi regresi yaitu 0,923 berarti bahwa keenam variabel memberikan kontribusi sebesar $92,3 \%$ pada hasil kedelai sedangkan sisanya 7,7\% adalah keragaman hasil yang berasal dari variabel lain di luar Model 1. Namun untuk sumbangan dari $\mathrm{x}_{6}$ sendiri pada hasil kedelai ditampilkan 
pada Tabel 10 yaitu 0,51 artinya dari 92,3\% variabel bobot 100 butir menyumbang sebanyak 51\% pada hasil kedelai dan sisanya dari variabel lain yaitu hanya sekitar $8 \%$.

Tabel 10. Operasi regresion statistics variabel $\mathrm{x}_{6}$ terhadap hasil kedelai dalam Model 1

\begin{tabular}{lc}
\hline & Regression Statistics \\
\hline Multiple R & 0,71 \\
R Square & 0,51 \\
Adjusted R Square & 0,46 \\
Standard Error & 3,28 \\
Observations & 12,0 \\
\hline
\end{tabular}

Bila dianalisis lebih lanjut, pengaruh variabel $\mathrm{x}_{1}$ sampai dengan $\mathrm{x}_{5}$ dapat diabaikan karena pengaruh kelima variabel tersebut tidak nyata $(\mathrm{P}>0,05)$ dan berkontribusi terlalu kecil pada hasil kedelai sehingga diperoleh model RLB yang baru, yaitu $\hat{y}=-2,57+0,083 \mathrm{x}_{6}$.

Pengaruh langsung Model 2 yaitu cara pemupukan satu kali ditampilkan pada (Gambar 4) yang menunjukkan bahwa variabel $\mathrm{x}_{5}$ (jumlah polong isi) memberikan kontribusi pengaruh langsung yang cukup besar pada hasil kedelai. Variabel $\mathrm{x}_{3}$ dan $\mathrm{x}_{4}$ memberikan pengaruh negatif sedangkan $\mathrm{x}_{1}, \mathrm{x}_{2}, \mathrm{x}_{5}$, dan $\mathrm{x}_{6}$ memberikan pengaruh positif pada hasil kedelai. Selain Gambar 4, diagram jalur model 2 ditampilkan juga pada Gambar 6 yang lebih rinci. Garis hijau pada diagram jalur menunjukkan besaran pengaruh langsung suatu variabel pada hasil kedelai. Variabel yang berpengaruh paling tinggi yaitu pada variabel $\mathrm{x}_{5}$ yang memiliki nilai 2,17 kemudian diikuti variabel $\mathrm{x}_{2}, \mathrm{x}_{6}, \mathrm{x}_{1}, \mathrm{x}_{3}$, dan $\mathrm{x}_{4}$ berturut turut nilainya $0,74,0,64,0,27,-1,16$, -1,40. Korelasi sangat dominan ditunjukkan oleh variabel jumlah polong total, jumlah polong isi, dan bobot 100 butir dalam memengaruhi hasil kedelai. Namun, dilihat dari nilai besaran korelasi, sumbangan $\mathrm{x}_{5}$ (jumlah polong isi) melalui $\mathrm{x}_{4}$ (variabel jumlah polong total) sangat tinggi yaitu 0,90 pada hasil kedelai. Hal ini berarti, tingkat pengisian fotosintat pada polong kedelai sangat baik sehingga menyebabkan jumlah polong isi tinggi.

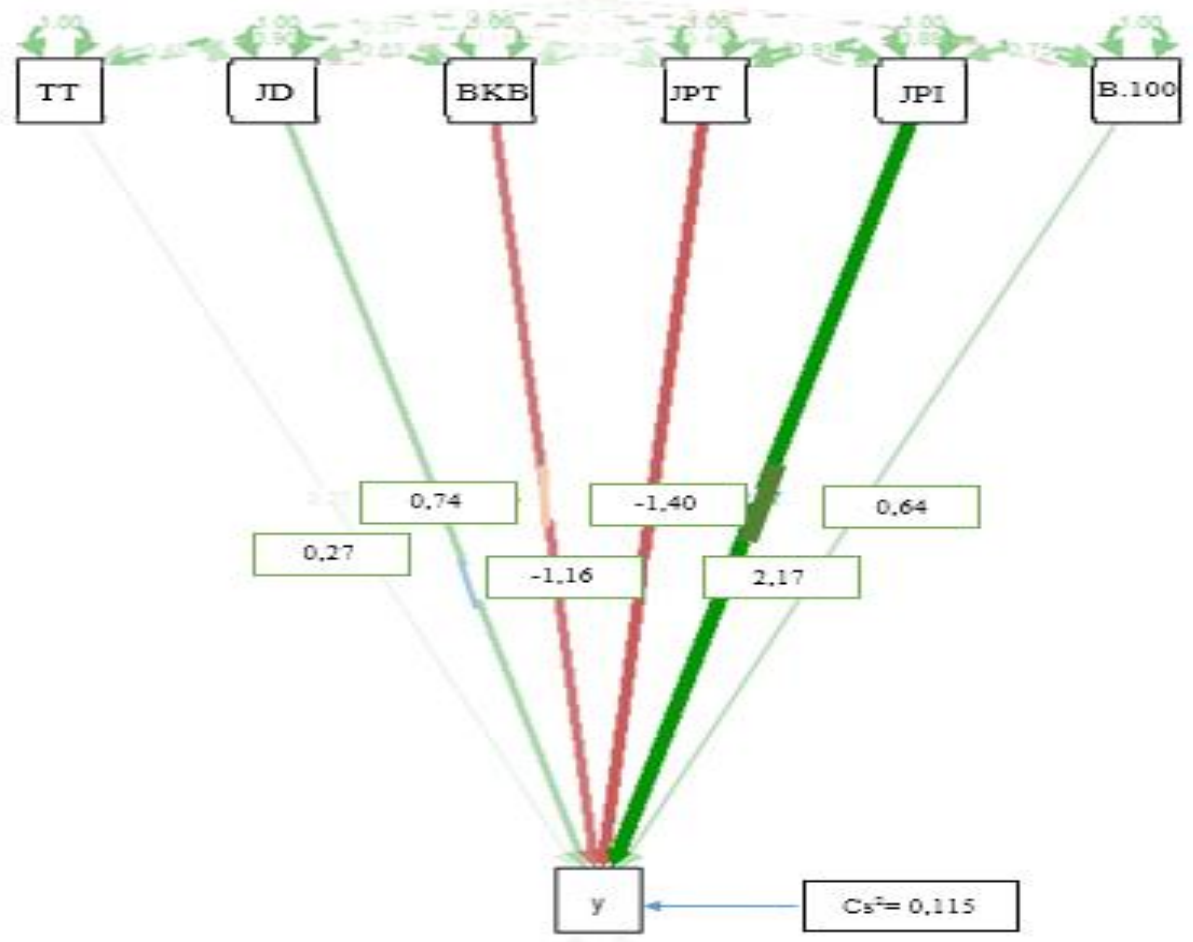

Gambar 6. Diagram lintasan pengaruh variabel eksogen $\mathrm{x}_{1}, \mathrm{x}_{2}, \mathrm{x}_{3}, \mathrm{x}_{4}, \mathrm{x}_{5}, \mathrm{x}_{6}$ pada variabel endogen $\mathrm{y}$. 
Timotiwu dkk : Analisis Jalur Respons Hasil Kedelai (Glycine max (L.) Merr.) Varietas Unggul Nasional...

Gambar 6 juga memberi informasi $\mathrm{t}$ ing persenta: eragaman vaı dbel endogen y yang disumbangkan oleh faktor lain dıuar model $\left(\mathrm{Cs}^{2}=1-\mathrm{R}^{2}\right)$ sehingga $\mathrm{R}^{2}=1-\mathrm{Cs}^{2}$. Menurut Ghozali, (2011), koefisien determinasi $\left(\mathrm{R}^{2}\right)$ digunakan untuk mengukur seberapa jauh kemampuan model dalam menerangkan variasi variabel di luar model. Nilai Adjusted $R$ Squared (R2) adalah koefisien determinasi yaitu koefisien yang menjelaskan seberapa besar proporsi variasi diluar model yang dapat dijelaskan oleh variabel - variabel dalam model secara bersama-sama. Nilai $\mathrm{R}^{2}$ ditampilkan pada Tabel 11.

Tabel 11. Operasi regresion statistics Model 2

\begin{tabular}{lc}
\hline & Regression Statistics \\
\hline Multiple R & 0,940874688 \\
R Square & 0,885245179 \\
Adjusted R Square & 0,747539393 \\
Standard Error & 0,055239349 \\
Observations & 12 \\
\hline
\end{tabular}

Nilai $\mathrm{R}^{2}$ yang diperoleh dari operasi regresi yaitu 0,885 , yang berarti bahwa keenam variabel memberikan kontribusi sebesar $88,5 \%$ pada hasil kedelai sedangkan sisanya $11,5 \%$ keragaman hasil yang dijelaskan oleh variabel lain di luar model 2. Namun untuk sumbangan dari $\mathrm{x}_{5}$ sendiri pada hasil kedelai ditampilkan pada Tabel 12 yaitu 0,76, artinya dari 88,5\% variabel jumlah polong isi menyumbang sebanyak $76 \%$ pada hasil kedelai dan sisanya dari variabel lain hanya sekitar $2 \%$.

Tabel 12. Operasi regresion statistics variabel $\mathrm{x}_{6}$ terhadap hasil kedelai dalam Model 2.

\begin{tabular}{lc}
\hline & Regression Statistics \\
\hline Multiple R & 0,875807583 \\
R Square & 0,767038922 \\
Adjusted R Square & 0,743742815 \\
Standard Error & 2,748322689 \\
Observations & 12 \\
\hline
\end{tabular}

Bila dianalisis lebih lanjut, pengaruh variabel $\mathrm{x}_{1}, \mathrm{x}_{2}, \mathrm{x}_{3}, \mathrm{x}_{4}$, dan $\mathrm{x}_{6}$ dapat diabaikan karena pengaruh kelima variabel tersebut tidak nyata $(\mathrm{P}>0,05)$ dan berkontribusi terlalu kecil pada hasil kedelai sehingga diperoleh model RLB yang baru, yaitu $\hat{y}=-0,417+0,043 x_{5}$.

Setelah diuji menggunakan Analisis Jalur untuk Model 1, variabel yang memberikan pengaruh nyata pada hasil kedelai yaitu $\mathrm{x}_{6}$ (bobot 100 butir) sedangkan pada model 2 yaitu $\mathrm{x}_{5}$ (jumlah polong isi). Penggunaan Analisis Jalur untuk pengembangan kriteria seleksi telah banyak dilakukan antara lain hasil penelitian (Li, et.all, 2013) mengatakan bahwa jumah polong isi per tanaman kedelai, jumlah biji per tanaman dan 100 biji mempunyai pengaruh langsung yang besar pada hasil kedelai.

Gambar 7 menggambarkan pola Model 1 dan Model 2. Model 1 menunjukkan pertumbuhan dan perkembangan lebih lambat dari Model 2. Pertumbuhan dan perkembangan yang lambat disebabkan oleh tingkat penyerapan unsur hara oleh tanaman. Berdasarkan analisis tanah setelah panen bahwa unsur P Model 2 lebih banyak diserap oleh tanaman daripada Model 1 ditunjukkan oleh besaran unsur P setelah panen. Analisis tanah unsur P di awal tanam yaitu 317,18 $\mu \mathrm{g} / \mathrm{g}$, Model 2 setelah panen nilainya menjadi 231,15 $\mu \mathrm{g} / \mathrm{g}$ sedangkan Model 1 nilainya 278,28 $\mu \mathrm{g} / \mathrm{g}$. Hal ini berarti tingkat penyerapan tanaman pada Model 2 
(pemupukan satu kali) terhadap unsur P lebih besar daripada Model 1 (pemupukan satu kali). Pemupukan dua kali lebih efisien dibandingkan pemupukan satu kali dalam penyerapan unsur $\mathrm{P}$ dan hasil kedelai lebih tinggi.

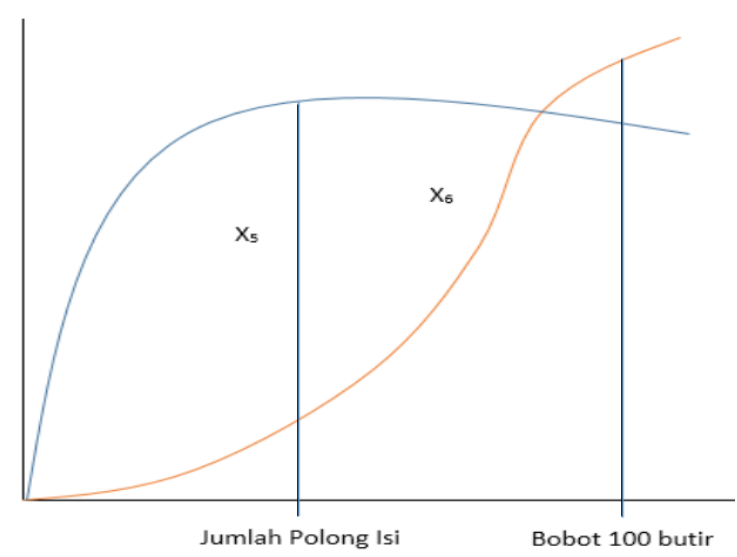

Gambar 7. Pola pengaruh variabel-variabel pada hasil kedelai.

$\begin{array}{cl}\text { Keterangan : Garis biru } & =\text { Model } 2(\text { cara pemupukan satu kali }) \\ \text { Garis merah } & =\text { Model } 1(\text { cara pemupukan dua kali }) \\ \text { X6 } & =\text { Bobot } 100 \text { butir } \\ \text { X5 } & =\text { Jumlah polong isi }\end{array}$

Menurut Adisarwanto, (2014), Pengaruh Unsur P pada tanaman sulit untuk dijelaskan secara detail, tetapi fungsi unsur $\mathrm{P}$ antara lain memacu terbentuknya bunga; menurunkan aborsitas, memperkuat batang sehingga tidak mudah rebah, dan memperbaiki kualitas kedelai. Adapun kekurangan unsur P menyebabkan pertumbuhan kerdil; jumlah anakan sedikit, dan daun meruncing berwarna hijau gelap. Berdasarkan analisis tanah setelah panen bahwa sebaliknya unsur $\mathrm{K}$ dalam penelitian ini bertambah kadarnya di dalam tanah. Analisis tanah unsur K di awal tanam yaitu 278,60 $\mu \mathrm{g} / \mathrm{g}$, Model 2 setelah panen nilainya menjadi 539,57 $\mu \mathrm{g} / \mathrm{g}$ sedangkan Model 1 nilainya 873,18 $\mu \mathrm{g} / \mathrm{g}$. Pemupukan dua kali (Model 1) menyebabkan penambahan unsur $\mathrm{K}$ lebih banyak dibandingkan dengan pemupukan satu kali (Model 2). Unsur K termasuk kedalam golongan yang mempunyai tingkat mobilitas sangat tinggi, selain unsur $\mathrm{N}$ dan $\mathrm{Na}$ sehingga penambahan unsur $\mathrm{K}$ pada Model 2 (pemupukan satu kali) lebih sedikit dibandingkan dengan Model 1 (pemupukan satu kali). Menurut Adisarwanto, (2014) menyatakan bahwa fungsi unsur K pada tanaman yaitu sebagai aktivator berbagai enzim. Kecukupan unsur kalium di dalam tanah menyebabkan tanaman tumbuh tegar, merangsang pertumbuhan, akar dan tanaman lebih tahan terhadap hama dan penyakit. Unsur $\mathrm{N}$ di dalam tanah, dalam penelitian ini tidak dianalis ketika awal tanam tetapi ada informasi setelah panen nilai $\mathrm{N}$ Model $1(0,27 \% \mathrm{w} / \mathrm{w})$ lebih tinggi daripada Model $2(0,22 \% \mathrm{w} / \mathrm{w})$. Dengan demikian pemupukan NPK pada Model 1 lebih efisien dibandingkan dengan Model 2. Dengan ketersediaan unsur N yang cukup pada Model 1, menyebabkan hasil kedelai cukup tinggi dibandingkan dengan Model 2. Periode puncak kebutuhan $\mathrm{N}$ bagi tanaman kedelai adalah pada fase awal berpolong (R3) sampai fase berbiji penuh (R6). Adisarwanto, (2014) menyatakan bahwa kebutuhan N pada fase ini tinggi dan $\mathrm{N}$ yang diserap dari tanah tidak mencukupi bila tidak diberikan tambahan pupuk.

Pemupukan sebaiknya dilakukan secara berimbang yang berarti disesuaikan juga dengan kondisi tanah. Hasil penelitian Rahman, dkk, (2013) menyimpulkan bahwa pemupukan NPK majemuk pada tanaman kacang hijau dengan dosis $300 \mathrm{~kg} / \mathrm{ha}$, berpengaruh nyata pada tinggi tanaman dan jumlah tangkai pada umur 30 HST dan 57 HST, serta berpengaruh nyata pada jumlah polong setiap tangkai, jumlah biji per polong, panjang polong, dan total produksi. Pupuk yang diberikan merupakan unsur tambahan sehingga jumlah Nitrogen, 
Timotiwu dkk : Analisis Jalur Respons Hasil Kedelai (Glycine max (L.) Merr.) Varietas Unggul Nasional...

Phospore, dan Kalium yang tersedia bagi tanaman berada dalam perbandingan yang tepat. Unsur hara $\mathrm{N}$ diberikan untuk menjaga pertumbuhan dan menyediakan karbohidrat yang cukup bagi pertumbuhan tanaman kedelai. Dalam memfiksasi N, tanaman kedelai dibantu oleh bakteri penambat $\mathrm{N}$ yaitu Rhizobium sp. Kondisi lingkungan yang menghambat pertumbuhan bakteri penambat $\mathrm{N}$ antara lain suhu rendah, kandungan $\mathrm{N}$ tinggi, kondisi air (kekeringan maupun genangan), dan pemadatan tanah. Unsur P yang ada dalam kandungan pupuk NPK berperan penting dalam sintesis ATP dan NADPH sebagai suplai energi dalam pembentukan bintil akar dan proses penambatan $\mathrm{N}_{2}$ oleh Rhizobium $s p$. Unsur $\mathrm{K}$ berperan penting dalam fotosintesis, karena secara langsung dapat meningkatkan pertumbuhan dan indeks luas daun, sehingga asimilasi $\mathrm{CO}_{2}$ juga meningkat dan berperan dalam meningkatkan translokasi hasil fotosintesis ke bagian akar yang digunakan oleh rhizobium (Rahman et al., 2013).

\section{KESIMPULAN}

Kesimpulan yang diperoleh dari penelitian ini yaitu pada cara pemupukan dua kali (Model 1) variabel yang berpengaruh langsung pada hasil produksi kedelai adalah bobot 100 butir sedangkan pada cara pemupukan satu kali (Model 2) variabel yang berpengaruh langsung pada hasil produksi kedelai adalah jumlah polong isi. Berdasarkan hasil penelitian yang telah dilakukan, disarankan untuk petani yang mempunyai modal untuk budidaya tanaman kedelai dapat melakukan model cara pemupukan dua kali, untuk mendapatkan produksi yang lebih tinggi dari pada pemupukan satu kali.

\section{DAFTAR PUSTAKA}

Maysaroh, S. (2018). Respons Pertumbuhan Dan Hasil Empat Varietas Kedelai (Glycine max (L.) Merill.) Terhadap Cara Pemberian Kombinasi Pupuk N P K. Universitas Lampung. Retrieved from http://digilib.unila.ac.id/31203/18/SKRIPSI TANPA BAB PEMBAHASAN.pdf

Adisarwanto, T. (2014). Kedelai Tropika: Produktivitas 3 ton/ha. Jakarta Timur: Penebar Swadaya.

Badan Pusat Statistik. (2012). Produksi Tanaman Kedelai (ton).

Badan Pusat Statistik. (2013). Produksi Tanaman Kedelai (ton). Retrieved from https://www.bps.go.id

Gaspersz, V. (1995). Teknik Analisis Dalam Penelitian Percobaan. Bandung: Penerbit Tarsito.

Ghozali, I. (2011). Aplikasi Analisis Multivariate Dengan Program IBM SPSS 19 (Edisi Keti). Semarang: Badan Penerbit Universitas Diponegoro.

Harlan, J. (2012). Persamaan Struktural. Jakarta: Universitas Gunadarma.

Kurniawan, D. (2008). Regresi Linier (Linier Regressio); Forum Statistika. Retrieved from https://www.academia.edu/6771017/linear_regression.

Li, Y.S., M. Du, Q.Y. Zhang, M. Hashemi, X. B. L. and S. J. H. (2013). Correlation and path coefficient analysis for yield and its components in vegetable soybean, Songklanakarin. Journal of Science and Technology, 34(3), 34(3), 273-277. https://doi.org/10.13140/2.1.1792.6408

Pedhazur, E. . (1982). Multiple Regression in Behavioral Research, Explanation and Prediction, second edition. CBS College Publishing. New York . (second edi). New York.: CBS College Publishing.

Rahman, R., W, M., Bahua, M. I., \& Nurmi, N. (2013). Pertumbuhan dan Produksi Kacang Hijau (Vigna radiata L.) Melalui Pemberian Pupuk Phonska, 1-10. Retrieved from http://kim.ung.ac.id/index.php/KIMFIIP/article/download/2469/2448

Sarwono, J. (2011). Mengenal Path Analysis: Sejarah, Pengertian, dan Aplikasi. Jurnal Ilmiah Manajemen Bisnis, 11(2), 285-296. Retrieved from http://www.jonathansarwono.info 
Jurnal Penelitian Pertanian Terapan

Susilo, F. X., \& Timotiwu, P. B. (2017). Penggunaan Regresi Untuk Analisis Data dan Riset Pertanian dan Biologi . . Bandar Lampung. $112 \mathrm{hlm}$. Bandar Lampung: Aura Cv. Anugrah Utama Raharja.

Wirnas, D., S. dan M. S. (2005). Pengembangan kriteria seleksi pada pisang (Musa sp.) berdasarkan analisis lintas. Buletin Agronomi (Vol. 33). Bogor. Retrieved from http://repository.ipb.ac.id/handle/123456789/35538 